\title{
PENGARUH ANALISIS FUNDAMENTAL DAN ANALISIS TEKNIKAL TERHADAP HARGA SAHAM PADA PERUSAHAAN YANG TERDAFTAR DI INDEKS LQ45
}

\author{
Christian Chandra Wijaya ${ }^{1}$, Arie Pratania Putri ${ }^{2}$ \\ Fakultas Ekonomi, Universitas Prima Indonesia \\ christianchandra998@gmail.com ${ }^{1}$, arieprataniaputri@gmail.com
}

\begin{abstract}
This research aims to determine whether technical analysis and fundamental analysis have an influence on the price of shares, both partially and simultaneously. The population in this study is 45 companies listed as members of the LQ45 index. In sampling, researchers coordinate the purposive sampling method, sampling by consideration of some criteria. The data used in this study is the financial statements of the company acquired from the website www.idx.co.id and the official website of the company itself. The research methods used in this study are a descriptive analysis method and multiple linear regression analysis methods. The results of this study show that partial current ratio has no effect and is insignificant to the stock price, the price earning ratio is influential and significant towards the stock price, the trading volume is influential and not significant to the stock price, and the Indeks Harga Saham Gabungan has no effect and is significant to the stock price. Simultaneously the current ratio, price earning ratio, trading volume, and Indeks Harga Saham Gabungan are influential and significant to the stock price.
\end{abstract}

Keywords: current ratio, price earning ratio, trading volume, and Indeks Harga Saham Gabungan

\section{PENDAHULUAN}

Di era globalisasi saat ini, investasi sudah merupakan hal yang diketahui hampir oleh setiap orang. Terdapat banyak jenis investasi yang legal di Indonesia. Salah satunya merupakan investasi pada pasar modal atau yang lebih dikenal sebagai saham. Tinggi rendahnya harga saham suatu perusahaan akan mempengaruhi kapitalisasi pasar suatu perusahaan dan akan mempengaruhi keputusan investasi suatu investor. Semakin besar kapitalisasi pasar perusahaan semakin tinggi daya tariknya terhadap investor. Berdasarkan artikel di finansialku.com pada tanggal 08 Juni 2017 (https://www.finansialku.com/definisi- kapitalisasi-pasar-adalah/) mengatahkan bahwa, dalam investasi portofolio, nilai kapitalisasi pasar memiliki makna yang penting bagi investor. Data kapitalisasi ini memiliki kekuatan yang mampu mempengaruhi minat investor untuk menjadikannya sebagai instrumen portofolio. Misalnya seperti yang disebut di atas, bahwa investor konservatif lebih condong memilih saham blue chip karena dirasa lebih aman. Pada umumnya memang semakin besar nilai kapitalisasi pasar suatu saham, maka semakin besar juga daya pikat saham tersebut bagi investor. Begitu pula sebaliknya, semakin kecil nilai kapitalisasi semakin kurang menarik bagi investor.

Selain melihat dari kapitalisai pasar suatu saham, para investor juga cenderung melihat likuiditas dari perusahaan untuk mengambil keputusan investasi. Indeks LQ45 merupakan 45 perusahaan yang memiliki likuiditas yang tinggi dan kriteria lainnya. Emiten yang terdaftar di Indeks LQ45 akan disesuaikan setiap enam bulan sekali yaitu tiap awal bulan Februari dan Agustus. Berdasarkan berita di insight.kontan.co.id Pada tanggal 24 juli 2019 (https://insight.kontan.id/news/5-saham-turun-ikut-ihsg-ini-10-saham-lq45-dengan-per-terkecil-23juli- 2019) mengatakan bahwa Indeks Harga Saham Gabungan (IHSG) ditutup turun pada perdangangan selasa (23/7). Ketika Bursa Efek Indonesia (BEI) mengakhiri hari perdagangan, IHSG turun 29,74 poin $(-0,46 \%)$ lalu mendarat diangka indeks $6.403,81$. Sejalan dengan penurunan IHSG, lima dari sepuluh saham LQ45 de ngan PER terendah turun dibanding penutupan sebelumnya. Sahamsaham yang mempunyai PER terendah adalah ADRO, PTBA, Elnusa Tbk (ELSA), Media Nusantara Citra Tbk (MNCN), dan Waskita Beton Precast Tbk (WSBP). Adapun Lima saham lain yang PER nya naik adalah SRIL, United Tractor Tbk (UNTR), Indo Tambangraya Megah Tbk (ITMG), Bank 
Tabungan Negara Tbk (BBTN), dan Medco Energy (MEDC). Beberapa penelitian terdahulu yang melakukan penelitian mengenai harga saham seperti penelitian yang dilakukan oleh Hantono;et;al (2019) yang menjelaskan bahwa current ratio terhadap harga saham tidak memiliki pengaruh yang signifikan, artinya dalam data ini tingkat kemampuan perusahaan dalam memenuhi kewajiban jangka pendeknya belum tentu dapat mempengaruhi harga saham perusahaan. Menurut Rahmadewi dan Abun Danti (2018), price earning ratio (PER) yang tinggi menunjukkan bahwa investor bersedia untuk membayar dengan harga saham premium untuk perusahaan. Menurut Andiani dan Gayatri (2018), semakin tinggi risiko bisnis suatu perusahaan maka dapat mempengaruhi harga saham. Menurut Choiriyah dan Indah (2018), adanya kegiatan jual beli saham menyebabkan perubahan yang signifikan terhadap harga saham. sehingga harga saham menjadi naik dan berdampak pada kenaikan indeks harga saham gabungan.

\section{Kajian Literatur}

\subsection{Teori Pengaruh Current Ratio (CR) terhadap Harga Saham}

Menurut Nurlia dan Juwari $(2019 ; 79)$ current ratio (CR) merupakan rasio yang mejelaskan kemampuan suatu perusahaan dalam memenuhi liabilitas lancarnya. Semakin tinggi nilai current ratio, menujukkan semakin tinggi likuiditasnya dan perusahaan dalam kondisi mampu melunasi semua liabilitas lancarnya. Hal ini tentu akan menarik perhatian dari investor dan akan meningkatkan aktivitas perdagangan yang akan berpengaruh terhadap peningkatan harga saham.

$$
\text { Current Ratio }=\frac{\text { Aktiva Lancar }}{\text { Kewajiban Lancar }} \times 100 \%
$$

\subsection{Teori Pengaruh Price Earning Ratio (PER) terhadap Harga Saham}

Menurut Ervinta \& Zaroni (2013;71) Perusahaan dengan rasio harga terhadap pendapatan yang rendah menarik lebih banyak investor dan menyebabkan peningkatan permintaan saham perusahaan. Meningkatnya permintaan saham perusahaan juga akan meningkatkan harga saham perusahaan. Hal ini dikarenakan perusahaan dengan price-to-earnings ratio memiliki keuntungan yang lebih tinggi dan akan menghasilkan return saham perusahaan yang lebih tinggi dan otomatis akan menarik perhatian

$$
\mathrm{PER}=\underline{\text { Earning Per Share }(\mathrm{EPS})}
$$

investor.

\subsection{Teori Pengaruh Volume Perdagangan Saham terhadap Harga Saham}

Menurut Arifannisa \& Nugraha $(2017 ; 420)$ Biasanya volume perdagangan menunjukkan naik turunnya harga saham di bursa. Oleh karena itu, tingkat penawaran dan permintaan pasar akan sangat mempengaruhi tren harga saham di bursa. Banyaknya transaksi saham dan kenaikan harga saham biasanya diartikan sebagai pertanda bahwa pasar sedang bullish. Kebalikannya juga benar, jika tekanan jual saham sangat tinggi dan harga saham turun, bisa diartikan bahwa pasar sedang melemah (bearish).

$$
\text { Volume Perdagangan Saham }=\frac{\text { Volume Perdagangan Invididual }}{\text { Volume Perdagangan Sektoral }}
$$

\subsection{Teori Pengaruh Indeks Harga Saham Gabungan (IHSG) terhadap Harga Saham}

Menurut Samsuar \& Akramunnas $(2017 ; 122)$ Kenaikan harga saham gabungan berarti menggambarkan atau menunjukan bahwa kondisi investasi dan perekonomian suatu negara tersebut sedang

bagus. Sebalikanya jika adanya penurunan berarti kondisi suatu investasi dan perekonomian suatu 
negara tersebut sedang buruk.

\section{IHSG $=$ IHSG AKHIR TAHUN}

\section{METODE PENELITIAN}

Penelitian ini menggunakan metode penelitian kuantitatif, yang dapat diartikan sebagai metode penelitian untuk meneliti populasi atau sampel tertentu. Analisis datanya bersifat kuantitatif atau statistik, dan bertujuan untuk menguji hipotesis yang telah ditentukan. Jenis penelitian yang digunakan dalam penelitian ini adalah kuantitatif.

\subsection{Populasi dan Sampel}

Menurut Nurlia \& Jurwali (2019;80), Populasi adalah bidang umum yang terdiri dari objek / topik dengan kualitas dan karakteristik tertentu, peneliti memutuskan untuk mempelajarinya dan kemudian menarik kesimpulan.

Menurut Nurlia \& Jurwali (2019;80), Sampel adalah bagian dari populasi dan karakteristiknya. Sampel dalam penelitian ini adalah perusahaan LQ45 yang terdaftar di Bursa Efek Indonesia (BEI) dari tahun 2016 sampai dengan 2018 yang memenuhi kriteria sampel. Penelitian ini menggunakan metode purposive sampling. Adapun kriteria-kriteria dalam pemilihan sampel dalam penilitian ini sebagai berikut:

1. Perusahaan LQ45 yang terdaftar di BEI periode 2016-2018

2. Perusahaan LQ45 yang mempublikasikan laporan keuangan secara rutin di BEI periode 2016 2018

3. Perusahaan LQ45 yang laba bersihnya positif periode 2016-2018

4. Perusahaan LQ45 yang memiliki data lengkap periode 2016-2018

Tabel 1. Tabel Pemilihan Sampel

\begin{tabular}{|l|l|c|}
\hline \multicolumn{1}{|c|}{ No } & \multicolumn{1}{|c|}{ Keterangan } & Jumlah \\
\hline 1. & $\begin{array}{l}\text { Perusahaan LQ45 yang terdaftar rutin sebagai anggota BEI selama } \\
\text { periode 2016-2018 }\end{array}$ & 45 \\
\hline 2. & $\begin{array}{l}\text { Perusahaan LQ45 yang tidak mempublikasikan laporan keuangannya } \\
\text { selama periode 2016-2018 }\end{array}$ & $(13)$ \\
\hline 3. & $\begin{array}{l}\text { Perusahaan LQ45 yang labanya negatif selama periode 2016-2018 } \\
\text { 4. }\end{array}$ & $\begin{array}{l}\text { Perusahaan LQ45 yang tidak memiliki data lengkap pada laporan } \\
\text { keuanga selama periode 2016-2018 }\end{array}$ \\
\hline & Jumlah sampel penelitian & $\mathbf{2 6}$ \\
\hline
\end{tabular}

Jumlah data yang ada pada sampel untuk digunakan dalam penelitian tersebut yaitu sebanyak 78 data, yang diambil dari total jumlah sampel sebanyak 26 perusahaan dikali dengan 3 tahun penelitian.

\subsection{Teknik Pengumpulan Data}

Teknik pengumpulan data yang digunakan dalam penelitian ini adalah menggunakan teknik studi dokumentasi yang artinya pengambilan data berupa laporan keuangan yang dipublikasikan di Bursa Efek Indonesia (BEI) melalui situs www.idx.co.id dan untuk situs perusahaan itu sendiri selama periode tahun.

\subsection{Jenis dan Sumber Data Penelitian}

Jenis penelitian yang digunakan dalam penelitian ini menggunakan penelitian kuntitatif. 
Menurut Sembiring (2017;37), Penelitian kuantitatif dapat dijelaskan sebagai metode penelitian yang didasarkan pada filosofi positivis, digunakan untuk mempelajari populasi atau sampel tertentu, teknik pengambilan sampel biasanya dilakukan secara acak, pengumpulan data menggunakan alat penelitian, analisis data bersifat statistik / kuantitatif, dan tujuannya untuk menguji yang telah ditetapkan. hipotesis.

\subsection{Identifikasi dan Definisi Operasional Variabel Penelitian}

Variabel yang digunakan dalam penelitian ini adalah variabel bebas yang terdiri dari analisis teknikal dan analisis dasar. Adapun definisi operasional masing-masing variabel adalah:

1. Variabel Independen (X) Menurut Nurlia \& Juwari (2019;81), Variabel independen atau variabel bebas adalah variabel yang mempengaruhi atau menyebabkan berubahnya atau munculnya variabel dependen. Variabel Independen dalam penelitian ini adalah Current Ratio (X1), Price Earning Ratio (X2), Volume Perdagangan (X3) \& Indeks Harga Saham Gabungan (X4).

2. Variabel Dependen (Y)

Menurut Nurlia \& Juwari $(2019 ; 82)$, Variabel terikat atau variabel dependen adalah variabel yang terpengaruh atau menjadi hasil akibat variabel bebas. Variabel terikat dalam penelitian ini adalah harga saham.

\subsection{Uji Asumsi Klasik}

Penelitian tersebut menggunakan uji asumsi klasik. Menurut Maga, Tommy \& Tulung (2016;414), uji asumsi klasik terdiri dari:
1. Uji Normalitas
2. Uji Multikolinearitas
3. Uji Heterokedastisitas
4. Uji Autokorelasi

\subsection{Metode Analisis}

Untuk menguji hipotesis digunakan model analisis statistik regresi linier berganda Persamaan statistik model tersebut adalah sebagai berikut:

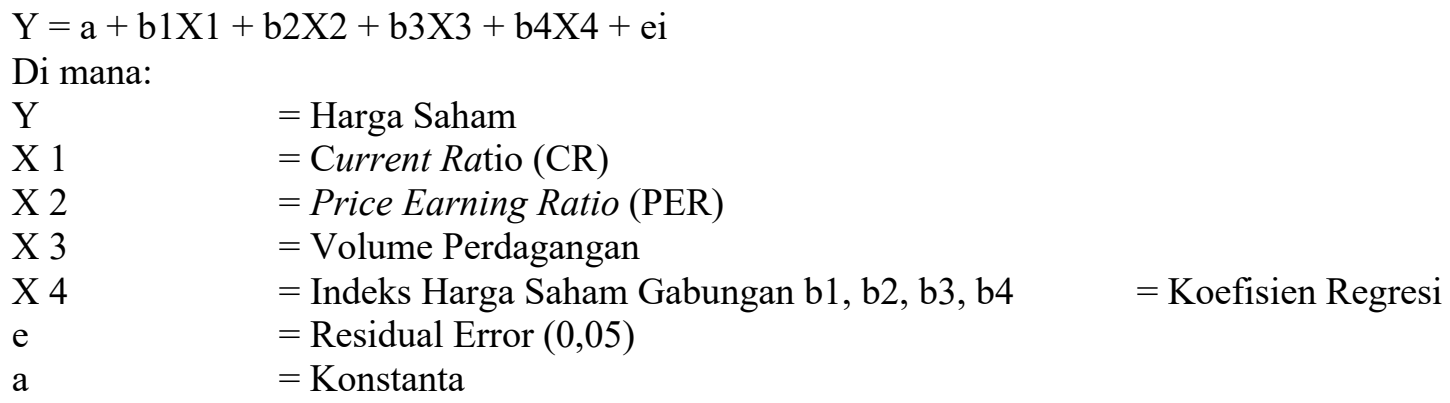

\subsection{Koefisien Determinasi Hipotesis (R2)}

Digunakan untuk mengetahui pengaruh persentase variabel independen terhadap perubahan variabel dependen. Dari sini kita dapat mengetahui berapa banyak variabel dependen yang dapat dijelaskan oleh variabel independen, dan sisanya dapat dijelaskan dengan alasan selain model. Koefisien determinasi adalah nol dan satu.

oleh variabel independen, dan sisanya dapat dijelaskan dengan alasan selain model. Koefisien determinasi adalah nol dan satu.

\subsection{Pengujian Hipotesis Secara Simultan (Uji F)}

Menurut Andriyani \& Armereo (2016;58), Uji statistik F pada dasarnya menunjukkan bahwa semua variabel independen atau variabel bebas yang termasuk dalam model mempunyai pengaruh yang sama terhadap variabel terikat.

Menurut Ghozali (2016:96), untuk menguji hipotesis ini digunakan statistik F dengan kriteria 
pengambilan keputusan yang membandingkan nilai $\mathrm{F}$ hasil perhitungan dengan nilai $\mathrm{F}$ menurut tabel, yaitu:

a. H0 diterima atau $\mathrm{Ha}$ ditolak jika Fhitung $<$ Ftabel dan nilai sig $>0,05$

b. Ha diterima atau $\mathrm{H} 0$ ditolak jika Fhitung $>$ Ftabel dan nilai sig $<0,05$

\subsection{Pengujian Hipotesis Secara Parsial (Uji t)}

Menurut Andriyani \& Armereo (2016;58), menyatakan bahwa Uji statistik t pada dasarnya menunjukkan seberapa jauh pengaruh satu variabel penjelas/independen secara individual dalam menerangkan variasi variabel dependen.

Menurut Ghozali (2016:97), Untuk menguji hipotesis ini digunakan statistik t bersama dengan kriteria keputusan yaitu membandingkan nilai t hitung dengan nilai t menurut tabel yaitu:

a. $\mathrm{H}_{0}$ diterima atau $\mathrm{H}_{\mathrm{a}}$ ditolak jika thitung $<$ tabel dan nilai sig $>0,05$

b. Ha diterima atau $\mathrm{H} 0$ ditolak jika thitung $>$ ttabel dan nilai sig $<0,05$

\section{HASIL PENELITIAN DAN PEMBAHASAN}

\section{1. $\quad$ Statistik Deskriptif}

Pada penelitian ini total perusahaan berjumlah 78. Berikut adalah statistik deskriptif dari nilai minimum, nilai maksimum, nilai rata-rata dan standar deviasi.

\begin{tabular}{lr|r|r|r|r} 
& \multicolumn{5}{c}{$\begin{array}{c}\text { Tabel 2. Statistic Deskriptif } \\
\text { Descriptive Statistics }\end{array}$} \\
& N & Minimum & Maximum & \multicolumn{1}{c}{ Mean } & Std. Deviation \\
\hline CR & 78 &, 380093 & 5,454664 & 2,21032365 & 1,288858452 \\
\hline PER & 78 & 1,206374 & 137,214671 & 20,54026560 & 20,241479950 \\
\hline VOLUME & 78 &, 000002 &, 845302 &, 05347062 & 101854502 \\
\hline IHSG & 78 & 5296,710000 & 6355,650000 & 5948,9533330 & 468,88974230 \\
& & & 0 & 0 \\
\hline HARGASAHAM & 78 & 230,000000 & 83800,000000 & 9940,5769230 & 17072,464720 \\
\hline Valid N (listwise) & 78 & & & 0 & 000 \\
\hline
\end{tabular}

Dari tabel diatas menunjukkan hasil nilai minimum, nilai maksimum, nilai rata-rata dan standar deviasi dari variabel Current Ratio, Price Earning Ratio, Volume Perdagangan, dan Indeks Harga Saham Gabungan dengan perincian sebagai berikut.

1. Hasil minimum dari variabel Current Ratio adalah 0,380093 yang dimiliki oleh PT. Jasa Marga (Persero), Tbk pada tahun 2018. Nilai maksimum adalah 5,454664 yang dimiliki oleh PT. Lippo Karawaci, Tbk pada tahun 2016. Dengan rata-rata 2,21032365 dan nilai standar devisiasi 1,288858452 .

2. Hasil minimum dari variabel Price Earning Ratio adalah 1,206374 yang dimiliki oleh PT. Astra International, Tbk pada tahun 2018. Nilai maksimum adalah 137,214671 yang dimiliki oleh PT. Sawit Sumbermas Sarana, Tbk pada tahun 2018. Dengan rata-rata 20,54026660 dan nilai standar.

devisiasi 20,241479950.

3. Hasil minimum dari variabel Volume Perdagangan adalah 0,000002 yang dimiliki oleh PT.Perusahaan Gas Negara, Tbk pada tahun 2016. Nilai maksimum adalah 0,845302 yang dimiliki oleh PT. Indofood CBP Sukses Makmur, Tbk pada tahun 2017. Dengan rata-rata 0,05347062 dan nilai standar devisiasi 0,101854502 .

4. Hasil minimum dari variabel Indeks Harga Saham Gabungan adalah 5296,710000 yang terdapat pada tahun 2016. Nilai Maksimum adalah 6355,650000 yang terdapat pada tahun 2017. Dengan rata-rata 5948,95333300 dan nilai standar devisiasi 468,889742300.

5. Hasil Minimum dari Variabel Harga Saham adalah 230,000000 yang dimiliki oleh PT. Sri Rejeki Isman, Tbk pada tahun 2016. Nilai Maksimum adalah 83800,000000 yang dimiliki oleh PT. 
Gudang Garam, Tbk pada tahun 2017. Dengan rata-rata 9940,57692300 dan nilai standar devisiasi 17072,46472000 .

\subsection{Uji Normalitas}

Uji normalitas digunakan untuk tujuan pengujian model regresi, variabel pengganggu atau residual berdistribusi normal. Jika uji normalitas dilanggar maka uji statistik menjadi tidak valid.

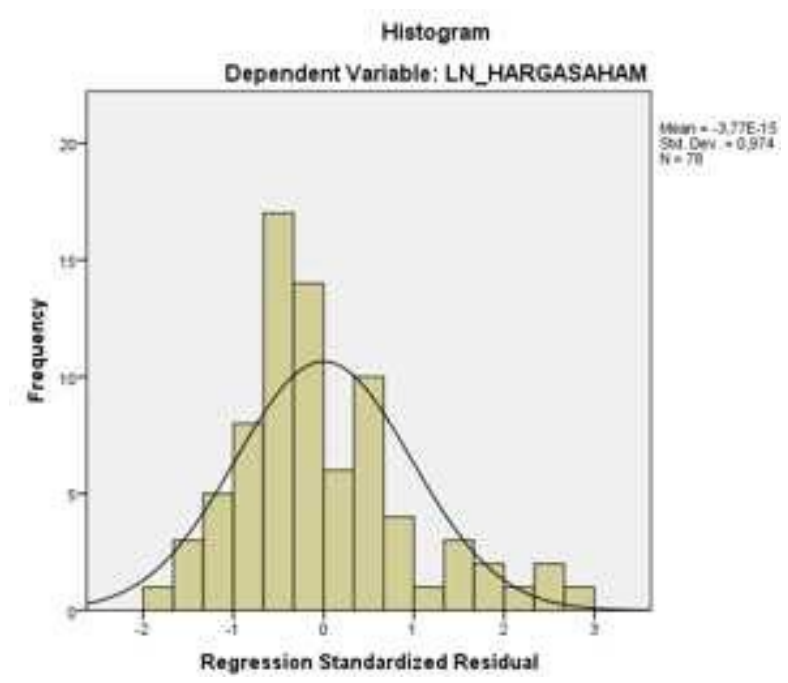

\section{Gambar 1. Uji Normalitas Histogram}

Histogram pada Gambar III.1 memperlihatkan data sebenarnya, membentuk kurva simetris (U) bukan kiri atau kanan, sehingga dapat dikatakan data berdistribusi normal.

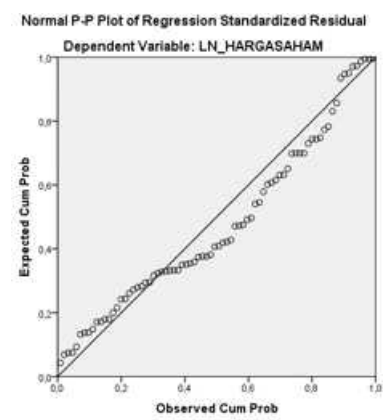

\section{Gambar 2. Uji Normalitas P-Plot}

Grafik normalitas P-Plot Pada Gambar III.2 di atas, kita dapat melihat titik-titik tersebar di sekitar diagonal. Sebarannya sebagian besar dekat dengan garis diagonal. 
Tabel 3. Uji Normalitas One-Sample Kolmogorov-Smirnov Test

Une-Sample Kolmogorov-Smirnov lest

\begin{tabular}{|c|c|c|}
\hline & & $\begin{array}{c}\text { Unstandardiz } \\
\text { ed Residual }\end{array}$ \\
\hline $\bar{N}$ & & 78 \\
\hline \multirow[t]{2}{*}{ Normal Parameters ${ }^{\mathrm{a}, \mathrm{b}}$} & Mean &, 0000000 \\
\hline & Std. Deviation & 1,05409827 \\
\hline \multirow[t]{3}{*}{ Most Extreme Differences } & Absolute &, 126 \\
\hline & Positive &, 126 \\
\hline & Negative & -.061 \\
\hline Test Statistic & &, 126 \\
\hline Asymp. Sig. (2-tailed) & &, $004^{c}$ \\
\hline \multirow{3}{*}{$\begin{array}{l}\text { Monte Carlo Sig. (2- } \\
\text { tailed) }\end{array}$} & Sig. & $.158^{\mathrm{d}}$ \\
\hline & $99 \%$ Confidence Interval Lower Bound &, 149 \\
\hline & Upper Bound &, 168 \\
\hline
\end{tabular}

a. Test distribution is Normal.

b. Calculated from data.

c. Lilliefors Significance Correction.

d. Based on 10000 sampled tables with starting seed 1314643744.

Hasil uji normalitas Kolmogorov Smirnov menunjukan nilai signifikan 0,158 >0,05 dengan demikian dari hasil uji Kolmogorov Smirnov dengan metode Monte Carlo yang menunjukkan data terdistribusi normal.

\subsection{Uji Multikolinearitas}

Uji multikolinearitas bertujuan untuk menguji apakah model regresi memiliki korelasi antara variabel independen. Model regresi yang baik tidak memiliki korelasi antar variabel independen. Pengujian ini dilakukan dengan melihat VIF antar variabel independen.

Tabel 4. Uji Multikolinearitas

\begin{tabular}{|c|c|c|c|}
\hline \multicolumn{4}{|c|}{ Coefficients $^{\mathrm{a}}$} \\
\hline \multirow[b]{2}{*}{ Model } & & Collinearity & tatistics \\
\hline & & Tolerance & VIF \\
\hline \multirow[t]{5}{*}{1} & (Constant) & & \\
\hline & LN_CR & 959 & 1,043 \\
\hline & LN_PER & 936 & 1,014 \\
\hline & LN VOLUME & 954 & 1,049 \\
\hline & LN IHSG & 976 & 1,025 \\
\hline
\end{tabular}

Pada tabel diatas, nilai tolerance pada variabel CR, PER, Volume Perdagangan dan IHSG berada diatas 0,10 sedangkan nilai VIF variabel CR, PER, Volume Perdagangan dan IHSG berada dibawah 10. Dengan demikian uji multikolinearitas tidak terjadi adanya korelasi antar variabel independen.

\subsection{Uji Autokorelasi}

Uji autokorelasi mempunyai tujuan untuk melihat apakah adanya perngaruh antara variabel bebas terhardap variabel terikat yang tidak boleh terjadinya korelasi antara observasi $(\mathrm{t})$ dengan data observasi sebelumnya (t-1). 
Tabel 5. Uji Autokorelasi

\begin{tabular}{|c|c|c|c|c|c|}
\hline \multirow[b]{2}{*}{ Model } & \multicolumn{4}{|c|}{ Model Summary ${ }^{b}$} & \multirow[b]{2}{*}{ Durbin-Watson } \\
\hline & $\mathbf{R}$ & R Square & $\begin{array}{c}\text { Adjusted R } \\
\text { Square }\end{array}$ & $\begin{array}{l}\text { Std. Error of } \\
\text { the Estimate }\end{array}$ & \\
\hline 1 & $602^{2}$ & 362 & 327 & 1,08259 & 1,781 \\
\hline
\end{tabular}

a. Predictors: (Constant), IHSG, PER, VOLUME, CR

b. Deperdent Variable: HARGASAHAM

Dari data tabel diatas, Durbin Watson (DW) menunjukan hasil 1,781.Untuk ketentuan uji autokorelasi yaitu $\mathrm{dU}<\mathrm{dW}<4$-dU. Jadi nilai $\mathrm{dU}=1,741$. Jadi hasil dari data pengujian tersebut adalah $1,741<$ $1,781<4-1,741$ maka hasilnya $1,741<1,781<2,259$. Maka dapat disimpulkan bahwa tidak adanya terjadi korelasi dalam penelitian tersebut.

\subsection{Uji Heteroskedastisitas}

Tujuan melakukan uji tersebut yaitu untuk mengetahui adanya penyimpangan syarat asumsi klasik yang terdapat pada regresi linier yang harus tidak adanya heteroskedastisitas.

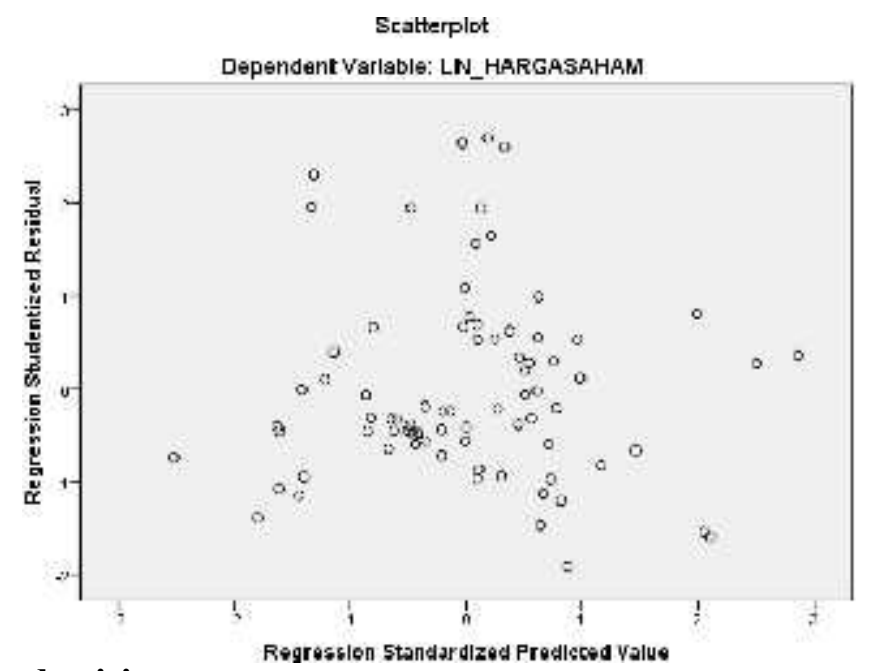

\section{Gambar 3. Uji Heteroskedastisitas}

Dapat dilihat dari scatter plot bahwa titik-titik di atas dan di bawah titik nol (0) pada sumbu Y terdistribusi dalam pola yang tidak jelas, bukan mengelompok di satu lokasi, sehingga dapat disimpulkan dari plot sebar tidak ada Heteroskedastisitas.

\subsection{Model Penelitian}

Uji hipotesis yang digunakan dalam penelitian ini adalah penggunaan analisis regresi linier berganda. Model regresi yang digunakan adalah sebagai berikut: 
Tabel 6. Model Penelitian

\begin{tabular}{|c|c|c|c|c|c|c|}
\hline \multirow[b]{3}{*}{ Model } & \multicolumn{6}{|c|}{ Coneffirients ${ }^{\mathrm{a}}$} \\
\hline & & \multicolumn{2}{|c|}{ Unstandardized Coefficients } & \multirow{2}{*}{$\begin{array}{l}\text { Standardized } \\
\text { Coefficients } \\
\text { Beta }\end{array}$} & \multirow[b]{2}{*}{$\mathbf{t}$} & \multirow[b]{2}{*}{ Sig. } \\
\hline & & B & Std. Error & & & \\
\hline 1 & (Cunstant) & 1,557 & 13,462 & &, 116 & $90 B$ \\
\hline & LN_CR &, 975 & 215 &, 133 & 1,532 &, 000 \\
\hline & LN_PER &, 740 & , 170 & .409 & 4,345 &, 000 \\
\hline & LN VOLUME & -.044 & .052 &,- 080 & -840 & .404 \\
\hline & LN IHSG &, 591 & 1,540 & 036 & 383 & 703 \\
\hline
\end{tabular}

a. Dependent Variable: LN_HARGASAHAM

Harga Saham $=1,557-0,975$ LN_CR + 0,740 LN_PER - 0,44 LN_Volume Perdagangan + 0,591 LN_IHSG

\subsection{Koefisien Determinasi Hipotesis}

Koefisien determinasi bertujuan untuk mengetahui seberapa besar dan jauh kemampuan model tersebut dalam menerangkan variabel terikat.

\section{Tabel 7. Uji Koefisien Determinasi}

\begin{tabular}{l|c|c|c|c} 
& \multicolumn{4}{c}{ Model Summary } \\
Model & R & R Square & $\begin{array}{c}\text { Adjusted R } \\
\text { Square }\end{array}$ & $\begin{array}{l}\text { Std. Error of } \\
\text { the Estimate }\end{array}$ \\
\hline $\mathbf{1}$ &, $602^{\mathrm{a}}$ &, 362 &, 327 & 1,08259 \\
\hline
\end{tabular}

a. Predictors: (Constant), IHSG, PER, VOLUME, CR

b. Dependent Variable: HARGASAHAM

Berdasarkan Tabel diatas, nilai koefesian determinasi adalah 0,327. Ini menunjukan bahwa 32,7\% variabel Harga Saham (Y) dapat dijelaskan oleh variabel CR (X1), PER (X2), IHSG (X3) dan Volume Perdagangan (X4). Sisanya hanya variabel lain yang tidak diteliti dalam penelitian ini.

\subsection{Pengujian Hipotesis Secara Simultan (Uji - F)}

Uji F digunakan untuk menunjukkan apakah semua variabel independen yang dimasukkan dalam model memiliki pengaruh yang sama terhadap variabel dependen.

Tabel 8. Uji F

\begin{tabular}{|c|c|c|c|c|c|c|}
\hline \multicolumn{7}{|c|}{ ANOVA ${ }^{a}$} \\
\hline \multicolumn{2}{|c|}{ Model } & $\begin{array}{l}\text { Sum of } \\
\text { Squares }\end{array}$ & Df & Mean Square & $\mathbf{F}$ & Sig. \\
\hline \multirow[t]{3}{*}{1} & Regression & 48,618 & 4 & 12,155 & 10,371 & $.000^{\circ}$ \\
\hline & Residual & 85,556 & 73 & 1,172 & & \\
\hline & Total & 134,175 & 77 & & & \\
\hline
\end{tabular}

Uji signifikansi simultan (Uji F) menghasilkan nilai $\mathrm{F}$ hitung sebesar 10,371. Pada derajat bebas $1(\mathrm{df} 1)=(\mathrm{k}-1)+1=(4-1)+1=4$ dan derajat bebas $2(\mathrm{df} 2)=\mathrm{n}-\mathrm{k}=78-4=74$ dimana $\mathrm{n}=$ jumlah sampel, $\mathrm{k}=$ jumlah variabel, maka nilai $\mathrm{F}$ tabel pada taraf kepercayaan signifikansi adalah 2,50. Dengan demikian dari hasil perhitungan SPSS diperolah nilai $\mathrm{F}$ hitung $=10,371>\mathrm{F}$ tabel $=2,50$. Dengan 
demikian tingkat signifikansi 0,000 karena $\mathrm{F}$ hitung $=10,371>\mathrm{F}$ tabel $=2,50$ dan probabilitas signifikansi $0,000<0,05$. Maka Ha diterima artinya variabel CR, PER, IHSG dan Volume Perdagangan berpengaruh dan signifikan terhadap variabel Harga Saham.

\subsection{Pengujian Hipotesis Secara Parsial}

Uji t digunakan untuk menunjukkan besarnya pengaruh suatu variabel bebas terhadap variabel terikat.

\section{Tabel 9. Uji t}

\begin{tabular}{|c|c|c|c|c|c|c|c|c|}
\hline & & & & efficients ${ }^{2}$ & & & & \\
\hline & & $\begin{array}{l}\text { Unstan } \\
\text { Coeff }\end{array}$ & $\begin{array}{l}\text { ardized } \\
\text { cients }\end{array}$ & $\begin{array}{l}\text { Standardize } \\
\text { d } \\
\text { Coefficients }\end{array}$ & & & $\begin{array}{r}\text { Collin } \\
\text { Stati }\end{array}$ & \\
\hline & & B & Std. Error & Beta & $t$ & Sig. & $\mathrm{e}$ & VIF \\
\hline 1 & (Constant) & 1,557 & 13,462 & &, 116 &, 908 & & \\
\hline & $\mathrm{IN} \mathrm{CR}$ & -975 & 215 & -433 & $-4,532$ &, 000 & ,955 & 1,043 \\
\hline & LN PER & .740 & 170 & $4 C 9$ & 4,345 & .000 & 986 & 1.014 \\
\hline & $\begin{array}{l}\text { IN_VOLU } \\
\mathrm{ME}\end{array}$ &,- 044 & 052 &,- 080 &,- 840 & .404 & $\$ 54$ & 1,049 \\
\hline & LN_LHSG & , 541 & 1.540 & .1030 & 383 &, 703 & $9 / 6$ & 1,025 \\
\hline
\end{tabular}

Nilai $t$ tabel untuk probabilitas 0,05 pada derajat bebas $n=78$ adalah sebesar 1,66462.

Dengan demikian hasil dari Uji t dapat dijelaskan sebagai berikut :

a. Pengaruh Current Ratio terhadap Harga Saham

Hasil perhitungan uji t secara parsial diperoleh nilai t hitung Current Ratio sebesar -4,532 dengan nilai $\mathrm{t}$ tabel sebesar 1,66462. Maka $\mathrm{t}$ hitung $<\mathrm{t}$ tabel $(-4,532<-1,66462)$ dengan nilai signifikannya 0,000 $<0,05$. Maka Ha ditolak dan Ho diterima yang artinya Current Ratio tidak berpengaruh positif dan tidaf signifikan terhadap Harga Saham.

b. Pengaruh Price Earning Ratio terhadap Harga Saham

Hasil perhitungan uji t secara parsial diperoleh nilai t hitung Price Earning Ratio sebesar 4,345 dengan nilai $\mathrm{t}$ tabel sebesar 1,66462. Maka $\mathrm{t}$ hitung $>\mathrm{t}$ tabel $(4,345>1,66462)$ dengan nilai signifikannya $0,000<0,05$. Maka Ha diterima dan Ho ditolak yang artinya Price Earning Ratio berpengaruh positif dan signifikan terhadap Harga Saham.

c. Pengaruh Volume Perdagangan terhadap Harga Saham

Hasil perhitungan uji $\mathrm{t}$ secara parsial diperoleh nilai $\mathrm{t}$ hitung Volume Perdagangan sebesar $-0,840$ dengan nilai $\mathrm{t}$ tabel sebesar 1,66462. Maka t hitung $>\mathrm{t}$ tabel $(-0,840>-1,66462)$ dengan nilai signifikannya $0,404>0,05$. Maka Ha diterima dan Ho ditolak yang artinya Volume Perdagangan berpengaruh positif dan tidak signifikan terhadap Harga Saham.

d. Pengaruh Indeks Harga Saham Gabungan terhadap Harga Saham

Hasil perhitungan uji $\mathrm{t}$ secara parsial diperoleh nilai t hitung Indeks Harga Saham Gabungan sebesar 0,383 dengan nilai $t$ tabel sebesar 1,66462 . Maka $t$ hitung $<\mathrm{t}$ tabel $(0,383<1,66462)$ dengan nilai signifikannya $0,703>0,05$. Maka Ha ditolak dan Ho diterima yang artinya Indeks Harga Saham Gabungan tidak berpengaruh positif dan signifikan terhadap Harga Saham.

\section{Pengaruh Current Ratio Terhadap Harga Saham}

Hasil Analisis menunjukkan bahwa Current Ratio tidak berpengaruh positif dan tidak signifikan terhadap harga saham dengan nilai $\mathrm{t}$ hitung $<\mathrm{t}$ tabel atau $-4,532<-1,66462$ dengan nilai signifikannya $0,000<0,05$. Dengan begitu, hasil penelitian ini tidak sejalan dengan hasil penelitian Nurlia \& Juwari (2019) yaitu Current Ratio tidak berpengaruh positif dan signifikan terhadap harga saham. Hasil penelitian ini dapat disimpulkan bahwa dengan semakin tingginya likuiditas akan 
menggambarkan bahwa perusahaan akan mampu dalam memenuhi kewajiban jangka pendeknya yang akan menarik investor untuk berinvestasi,

sehingga dengan banyaknya investor akan tertarik untuk melakukan investasi maka akan dapat meningkatkan penawaran saham di perusahaan tersebut.

\section{Pengaruh Price Earning Ratio Terhadap Harga Saham}

Hasil Analisis menunjukkan bahwa Price Earning Ratio berpengaruh positif dan signifikan terhadap harga saham dengan nilai $\mathrm{t}$ hitung $>\mathrm{t}$ tabel atau 4,345 $>1,66462$ dengan nilai signifikannya 0,000

$<0,05$. Dengan begitu, hasil penelitian ini sejalan dengan hasil penelitian Ervinta \& Zaroni (2014) yaitu Price Earning Ratio berpengaruh signifikan terhadap harga saham. Hasil penelitian ini dapat disimpulkan bahwa meningkatnya PER, akan menarik perhatian investor untuk menginvestasikan modalnya di perusahaan sehingga harga saham akan mengalami peningkatan, yang artinya semakin tinggi PER, maka akan semakin tinggi pula harga saham perusahaan.

\section{Pengaruh Volume Perdagangan Terhadap Harga Saham}

Hasil Analisis menunjukkan bahwa Volume Perdagangan berpengaruh positif dan tidak signifikan terhadap harga saham dengan nilai $t$ hitung $>t$ tabel atau $-0,840>-1,66462$ dengan nilai signifikannya 0,404 $>0,05$. Dengan begitu, hasil penelitian ini tidak sejalan dengan hasil penelitian Arifannisa \& Nugraha (2017) yaitu Volume Perdagangan tidak berpengaruh signifikan terhadap harga saham. Hasil penelitian ini dapat disimpulkan bahwa Volume perdagangan hanya dapat menunjukkan berapa banyaknya lembar saham yang di perjual belikan selama beberapa periode waktu tertentu saja. Maka semakin banyak lembar saham yang diperjual belikan semakin besar pula kemungkinan terjadi perubahan harga saham tersebut.

\section{Pengaruh Indeks Harga Saham Gabungan Terhadap Harga Saham}

Hasil Analisis menunjukkan bahwa Indeks Harga Saham Gabungan tidak berpengaruh positif dan signifikan terhadap terhadap harga saham dengan $\mathrm{t}$ hitung $<\mathrm{t}$ tabel atau 0,383 $<1,66462$ dengan nilai signifikannya $0,703>0,05$. Dengan begitu, hasil penelitian ini tidak sejalan dengan hasil penelitian Samsuar \& Akramunnas (2017) yaitu Indeks Harga Saham Gabungan berpengaruh positif dan tidak signifikan terhadap harga saham. Hasil penelitian ini dapat disimpulkan bahwa nilai IHSG yang mengalami penurunan mencerminkan lebih banyak harga saham di bursa yang mengalami penurunan daripada harga saham yang mengalami kenaikan.

\section{KESIMPULAN}

Dari hasil penelitian tersebut diperoleh kesimpulannya sebagai berikut:

1. Current Ratio secara parsial tidak berpengaruh dan tidak signifikan terhadap harga saham pada perusahaan LQ45 periode 2016-2018 sehingga hipotesis pertama dalam penelitian ini ditolak.

2. Price Earning Ratio secara parsial berpengaruh dan signifikan terhadap harga saham pada perusahaan LQ45 pada periode 2016-2018 sehingga hipotesis kedua dalam penelitian ini di terima.

3. Volume Perdagangan secara parsial berpengaruh dan tidak signifikan terhadap harga saham pada perusahaan LQ45 periode 2016-2018 sehingga hipotesis ketiga dalam penelitian ini ditolak.

4. Indeks Harga Saham Gabungan secara parsial tidak berpengaruh dan signifikan terhadap harga saham pada perusahaan LQ45 periode 2016-2018 sehingga hipotesis keempat dalam penelitian ini ditolak.

5. Current Ratio, Price Earning Ratio, Volume Perdagangan, dan Indeks Harga Saham Gabungan secara simultan berpengaruh dan signifikan terhadap harga saham pada perusahaan LQ45 periode 2016-2018 sehingga hipotesis kelima dalam penelitian ini diterima. 


\section{REFERENSI}

Andiani, N., \& Gayatri. (2018). Pengaruh Volume Perdagangan Saham, Volatilitas Laba, Dividend Yield, Dan Ukuran Perusahaan Pada Volatilitas Harga Saham. ISSN: 2302-8556 E-Jurnal Akuntansi Universitas Udayana, 24(3), 2148-2175.

Andriyani, I., \& Armereo, C. (2016). Pengaruh Suku Bunga, Inflasi, Nilai Buku Terhadap Harga Saham Perusahaan Indeks LQ45 yang Terdaftar Di Bursa Efek Indonesia. Jurnal Ilmiah Orasi Bisnis. Vol 15, Hal 56-57.

Arifannisa, W., \& Nugraha, A. (2017). Pengaruh Faktor-Faktor Fundamental dan Faktor-Faktor Teknikal Terhadap Harga Saham (Studi Empiris Pada Perusahaan Manufaktur Sektor Industri Barang Konsumsi yang Terdaftar Di Bursa Efek Indonesia Periode 2013-2015). Profesionalisme Akuntan Menuju Sustainable Business Practice ISSN: 2252-3936.

Choiriyah, S., \& Yuliana, I. (2018). Hubungan harga saham, volume perdagangan, inflasi dan indeks harga saham gabungan pada perusahaan sub sector makanan dan minuman di bei. Seminar Nasional dan Call for Paper: Manajemen, AkuntansidanPerbankkan 2018 Hal 860-873.

Daniel. (2015). Pengaruh Faktor Internal Terhadap Harga Saham Pada perusahaan Lq 45 Yang Terdaftar Di Bursa Efek Indonesia. Jurnal Emba 863 vol.3 no.3 sept. 2015, hal.863-876 issn 2303-11.

Ervinta, T., \& Zaroni. (2013). Analisis Pengaruh Faktor Fundamental Dan Eva Terhadap Harga Saham Indeks LQ-45 Yang Terdaftar Di Bursa Efek Indonesia Periode 2007-2011. Bina Ekonomi Majalah Ilmiah Fakultas Ekonomi Unpar. Vol 17 No.1, Hal 71.

Ghozali, I. (2016). Aplikasi Analisis Multivariate Dengan Program IBM SPSS 23. Semarang : Penerbit Universitas Diponegoro.

Hantono, Sari I., Chiquita, Levina, Gloriana M., \& Sabaryanti. (2019). Pengaruh Debt To Equity Ratio, Current Ratio, Business Risk, Firm Size, Book Value Terhadap Harga Saham (Studi Kasus Pada Sektor Industri Dasar dan Kimia). Jurnal Ilmiah ESAI Volume 13 No. 2, Juli 2019 p-ISSN 19786034 e-ISSN 2580-4944.

Fun, L. \& Basana S. (2012). Price Earnings Ratio and Stock Return Analysis (Evidence from Liquidity 45 Stocks Listed in Indonesia Stock Exchange). Jurnal Manajemen dan Kewirausahaan, vol.14, no. 1, Maret 2012: 7-12.

Maga, Y., Tommy P., \& Tulung J. (2016). Analisis Struktur Modal, Profitabilitas dan Struktur Aktiva Terhadap Nilai Saham Pada Perusahaan Tekstil Dan Garmen Yang Terdaftar Di Bursa Efek Indonesia Periode 2011-2014.Jurnal EMBA. Vol 4 No.3, Hal 414.

Moorcy, N. (2018). Faktor-faktor Yang Mempengaruhi Harga Saham Perusahaan Food \& Beverages Yang Terdaftar Di Bursa Efek Indonesia. Jurnal GeoEkonomi ISSN: 2503-4790, Hal 25.

Nurlia, \& Juwari. (2019). Pengaruh Return On Asset, Return On Equity, Earning Per Share dan Current Ratio terhadap Harga Saham pada Perusahaan Sub Sektor Otomotif dan Komponen yang Terdaftar Di Bursa Efek Indonesia.Jurnal GeoEkonomi ISSN: 2503-4790, Hal 79.

Rahmadewi, P., \& Abundanti N. (2018). Pengaruh Eps, Per, Cr, Dan Roe Terhadap Harga Saham Di Bursa Efek Indonesia. E-Jurnal Manajemen Unud, Vol. 7, No. 4, 2018: 2106-2133. ISSN : 23028912.

Saerang, D., \& Pontoh W. (2011). Analisis Pengaruh Tingkat Pengembalian Aktiva Terhadap Harga Saham Perusahaan di Bursa Efek Indonesia. Jurnal riset akuntansi dan auditing goodwill. Vol. 2 no. 2 desember 2011 issn. 2088-8899.

Samsuar, T., \& Akramunnas. (2017). Pengaruh Faktor Fundamental dan Teknikal Terhadap Harga Saham Industri Perhotelan yang Terdaftar Di Bursa Efek Indonesia. Mashrafiyah Jurnal Ekonomi, Keuangan dan Perbankan Syariah. Vol 1 No.1, Hal 122.

Sembiring, M. (2017). Analisis Pengaruh Pertumbuhan Ekonomi dan Inflasi Terhadap Harga Saham Pada Perusahaan Real Estate dan Property Yang Terdaftar di Bursa Efek Indonesia Periode $2011-2015$. 